\title{
Few large with many small: banks size distribution and cross-border financial linkages*
}

\author{
Giorgio Barba Navaretti ${ }^{1}$, Giacomo Calzolari ${ }^{2}$, Alberto Franco \\ Pozzolo $^{3}$, and Maria Teresa Trentinaglia de Daverio ${ }^{4}$ \\ ${ }^{1}$ University of Milan, Centro Studi Luca D'Agliano \\ ${ }^{2}$ University of Bologna, CEPR, Centro Studi Luca D'Agliano \\ ${ }^{3}$ University of Molise, Mo.Fi.R., Centro Studi Luca D'Agliano \\ ${ }^{4}$ University of Milan, Centro Studi Luca D'Agliano
}

May 4, 2019

\begin{abstract}
We estimate the effect of the distribution of banks by asset size on a country's propensity to engage in cross-border banking. Countries where the distribution of banks by asset size is more skewed to the right (with few large and many small banks) lend more abroad and are recipients of more funds from foreign banks. This is consistent with the fact that large banks, with easier access to the international financial markets, act as a hub for smaller banks and at the same time stand out as safer too-big-to fail counterparts for foreign partners.
\end{abstract}

JEL classification: F32, F36, F65, G21

Keywords: BIS International banking statistics, bank size, gravity equations

${ }^{*}$ We would like to thank an anonymous reviewer for excellent comments, and also Rebel Cole (discussant), Travis Selmier II (discussant), Olivier De Jonghe, and seminar participants at the Portsmouth-Fordham Conference on Banking \& Finance, 24-25 September 2016, at the Rome International Conference on Money Banking and Finance, 1-2 December 2016, and at the 2016 World Finance and Banking Symposium in Dubai, 15-16 December 2016. Giorgio Barba Navaretti acknowledges funding by the Centro Studi Luca d'Agliano within the project "Banks heterogeneity and capital flows". The usual disclaimers apply. 


\section{Introduction}

The surge in bilateral gross international financial flows is a distinguishing feature of globalization. Lane and Milesi-Ferretti (2007) show that the ratio of the sum of external assets and liabilities over GDP has grown by a factor of 7 over 1970-2004, from $45 \%$ to over $300 \%$, with a strong acceleration starting in the mid1990s. Indeed, financial globalization has outstripped the growth of trade. And although the recent financial crisis has determined a temporary stop in the process, at least in some countries, ${ }^{1}$ the long-run trend still points in the direction of further integration among both developed and developing countries.

Ample evidence suggests that a prominent role in this process of international financial integration is played by major financial institutions, in particular multinational banks. Furthermore, the 2007-2008 financial crisis has shown that large gross cross-border interbank positions were a major cause of the worldwide instability of the financial system (Caballero, 2010; Haldane, 2009).

Building on these stylized facts, this paper examines the role played by the characteristics of the banking industry in each country on cross-border banking positions, with a particular focus on the distribution of bank size. The analysis is nested within a two stage gravity framework.

Gravity equations provide a natural setting for studying patterns of international integration, including cross-border banking activities. Despite some limitations in their theoretical justifications (but see Martin and Rey, 2004; Head and Ries, 2008; Okawa and van Wincoop, 2012), the empirical literature has shown that gravity-like equations can go a long way in explaining not only the pattern of bilateral trade but also that of cross-border financial positions (Portes and Rey, 2005; Daude and Fratzscher, 2008). As in the trade literature, a large number of factors have been found to impact on the strength of bilateral cross-border linkages in financial markets, from country size and geographical distance, to institutional and cultural differences, to characteristics of the origin and destination countries, such as the development of the domestic financial system.

An aspect that so far has been overlooked in the literature is the structure of the banking sector in each country (origin and destination), including the distribution of banks by size, the degree of competition, the presence of foreign intermediaries. Industry sector characteristics have been shown to exercise a crucial impact on countries' international trade patterns, and firm size distribution is a key statistic in the "new-new" trade theory (Melitz, 2003), both on exports and on imports (Bernard et al., 2007). We are interested to investigate whether this is also the case for banks' financial claims.

Interestingly, adopting the framework of gravity equations, Barba Navaretti et al. (2015) and Pietrovito et al. (2013) have recently shown that it is not only the average firm size-that matters, $\Rightarrow$ it also higher moments measuring the asymmetry of the distribution by size, such as skewness. While the same case can presumably be made for financial transactions, the empirical literature on the the patterns of

${ }^{1}$ see, for example, (Buch et al., 2014b; Amiti et al., 2017). 


\section{size}

cross-border interbank integration has so far ignored the role of the distribution of financial institutions by their size.

This paper aims at filling these gaps in the literature. Following Eaton and Kortum (2002) and Head and Ries (2008), we adopt a two-steps empirical methodology. First, we estimate a standard gravity model on the bilateral international claims from BIS Consolidated Banking Statistics data (CBS), including bilateral characteristics and country fixed effects. Second, we regress different moments of the distribution of bank by asset size on the fixed effects estimated in the first stage gravity regression, controlling for a set of other country specific characteristics. We control very carefully especially for the degree of competition in the banking industry, because bank size can indeed be related to he degree of competition in the market, and for the presence of foreign bank ownership, as this may in principle mechanically affect the results, as further discussed below.

Our results show that higher moments of the distribution of banks by asset size are significantly related to the patterns of bilateral cross-border financial integration, consistent with findings in the domain of international trade Barba Navaretti et al. (2015).

by

In particular, we find convincing evidence that countries where the distribution of banks by asset size is more right-skewed, i.e. with few large banks together with many small ones, lend and receive larger amounts of funds internationally. This result is on top of the common effect, that we also identify, that a larger average size of the banks in a country implies more funds from foreign banks. The result is also independent of the degree of competition in the banking sector and foreign ownership. Once again, it's important to note that the result does not refer to the known effect of large banks, but rather on the asymmetry in the distribution of banks' size in a country.

Why few large banks coexisting with many small ones are able to lend more abroad and to attract more foreign funding? We reasonably expect that holders, and especially recipients of foreign claims, are the few large banks and not the many small ones in the countries with more skewed distributions. One may think that the presence of multinational banks plays a role in our results. These large banks in countries with skewed distributions may be multinational banks which have better access to the international inter-bank market, especially across their own affiliates. For this reason, in the second stage we explicitly take into account the impact of both modes of the bank internationalization process, controlling for the presence of foreign subsidiaries in each country, and for the number of foreign subsidiaries that banks in each country hold abroad. Moreover, since we use international claims, we exclude (by definition of international claims) the local claims of foreign affiliates in the local currency. Although international claims still account for local claims in foreign currency of foreign affiliates, Barba Navaretti et al. (2010) provide evidence that at the aggregate level they are of very limited relevance. Therefore, one should rather focus on understanding why large banks are seen as more interesting and safer partners in a country when they are associated with many small competitors there. We think that these countries with skewed distributions of banks are characterized by a dual banking system with the few large banks standing out, both from the 
view point of their foreign lenders and in terms of their specialization in domestic lending, as we now explain.

As for specialization, in a dual banking system, large banks may efficiently focus on lending to large and transparent firms, whilst the small banks are typically specialized in lending to more opaque SMEs (e.g., Berger et al., 2005). When instead banks are of more similar size, they specialize less and may then end up being less efficient. In the end, they turn out to be less capable of accessing international markets. Fixed costs and scale economies may also play a role in specializing and activating international financial transactions with banks of a foreign a country. These costs are typically on both sides of a bank's activity, lending and borrowing. The larger the scale of international financial transactions the lower is the pertransaction cost. In a dual banking environment, the large bank can operate as an efficient gateway for their own transactions (lending and borrowing) but also for those of the many small banks through, for example, the domestic inter-bank market. When instead the banks are of more similar size, some of the largest banks could still afford the cost of dealing internationally although at a lower and less efficient scale.

Consider now the perception of foreign lenders. From their view point, larger banks may be willing to take on larger risks by acquiring foreign claims, and foreign lenders ready to deal with them, due to an implicit subsidy for too-big-to-fail banks. From the view point of foreign partners, lending to a country could be safer when a few large banks clearly stand out as too-big-too fail in a country, in contrast with many medium-sized banks that could be left failing in case of distress. This implicit public guarantee makes the few large banks in the country with skewed banking system relatively safer and then more attractive for cross-border lending.

The rest of the paper is organized as follows: Section 2 briefly reviews the literature that is most relevant for our analysis; Section 3 describes the sources of the data used in the empirical analysis; Section 4 explains the identification strategy and the econometric methodology adopted; Section 5 presents the baseline results, and Section 6 a number of robustness checks. The last Section concludes and discusses some policy implications.

\section{Literature}

This paper refers to three major strands of literature. Starting from the literature on internationalization and firm size (e.g., Melitz, 2003), it contributes to the literature on gravity models, in particular those focusing on the explanation of financial transactions (e.g., Portes and Rey, 2005; Daude and Fratzscher, 2008), as well as to the literature on financial globalization and cross-border financial linkages (e.g., Buch et al., 2014b; Niepmann, 2015).

New-new trade literature has emphasized the role of the size of firms as a key determinant of their degree of internationalization, with respect to both exports (e.g., Melitz, 2003) and foreign direct investments (Helpman et al., 2004, e.g.,). And indeed a large strand of empirical literature has confirmed the theoretical 
predictions, showing that larger firms are more international (see, e.g., Ottaviano and Mayer, 2011). Also for financial intermediaries, size is a major determinant of the degree of internationalization (see, e.g., Focarelli and Pozzolo, 2005, in the case of cross-border bank M\&As). These results hinge on the hypothesis that there are significant fixed costs in the process of internationalization, that only the larger firms and banks can overcome in order to reap the benefits of accessing larger markets. Our analysis contributes to this literature verifying if these empirical regularities ffixed costs are confirmed also in the case of bank cross-border as holdings, in particular when associated with a skewed distribution of banks.

The second strand of literature related to our analysis is that of empirical gravity models. Gravity models are usually used to identify the drivers of trade flows between countries. Starting from the very basic equation, in which geographical distance and each country's size explains the volume of bilateral trade (Timbergen (1962)), gravity models typically include both bilateral characteristics - such as the distance between two countries or whether they share a common border, that are defined dyadic characteristics because they describe the relationship between country couples - as well as separate characteristics of each country involved in a transaction. The empirical literature following the first specifications has progressively augmented the set of both country specific and dyadic variables that are assumed to contribute to the explanation of bilateral flows.

Only recently firms heterogeneity has been added in structural estimations of gravity models (see Head and Mayer, 2014, for a survey). Within the standard trade model with heterogeneous firms á la Melitz (2003) only first moments of productivity distributions are shown to have an impact on aggregate trade flows. But several recent contributions have shown that the restrictive conditions of the standard trade model (Pareto distributions, CES demand functions and iceberg trade costs) do not stand to empirical scrutiny (e.g., Base et al., 2015; Melitz and Redding, 2015). In particular, Barba Navaretti et al. (2015) shows that aggregate exports are not only associated to firms' average productivity but also to higher moments of the distribution, measuring dispersion and asymmetry. Our contribution follows Barba Navaretti et al. (2015), to examine whether aggregate cross-border banking activities are somehow related to different moments of banks' size distributions.

Gravity models are also embedded in the analysis of international financial transactions, that is closer to our contribution. Existing results confirm that geographical distance is detrimental not only to trade flows, but also to financial flows. For instance, this is the outcome of Portes and Rey (2005), who estimate the role of market size, trading technologies and distance in explaining international asset transactions. Despite their virtual and intangible nature, the volume of traded assets is negatively affected by distance, which may account for informational frictions. Information costs are also at the core of the analysis of Daude and Fratzscher (2008), who observe a pecking order in cross-border capital investments as countries become more financially integrated. The behavior of these alternative capital investments may stem from information frictions and/or the quality of institutions in the host country. Interestingly, FDI and loans are more sensible than other port- 
folio investment instruments to information frictions, captured by physical distance and other measures. ${ }^{2}$ Moreover, FDI and loans are less sensitive to institutions' quality - measured by expropriation risks, reputation costs, and corruption degrees - which may instead better explain the direction of other portfolio investments. The institutional background is also at the center of Papaioannou (2009) who, among others, observe that institutions and size, measured by GDP, enhance a country's ability to attract cross-border claims from abroad.

Apart from geographical distance, transaction and information costs may also arise because of cultural differences between countries. Kleimeier et al. (2014) consider the relation between cultural differences and financial integration and disintegration during normal times as well as financial crises. They exploit data on the deposits of the Euro area from 1999 to 2011, and split their analysis before and after 2007. They observe that, shortly after 2002, a general feeling of financial stability and confidence in the new single currency, also called "Europhoria", promoted cross-border deposits, counterbalancing cultural distance. After the 2007 financial crises, instead, this pattern was reversed. The single currency was no longer able to offset cultural differences, and the Eurozone experienced a period of financial disintegration and a decline in cross-border deposits.

Gravity models may also explain the role of banks in facilitating firms' access to foreign markets. Schmidt-Eisenlohr (2013), for instance, embed the joint effect of geographical distance and financing costs in a standard gravity equation of international trade, and observes that financing costs, measured by interest rate margins, hamper trade, and the effect increases with distance. In a similar vein, Niepmann and Schmidt-Eisenlohr (2013) show that international trade related financing increases with the level of aggregate risks and exhibits a hump-shaped pattern in country-specific risk. Interestingly, the negative effect of distance is once again confirmed: an increase in the time required to trade does not only hamper international trade, but it also reduces trade finance.

These findings are broadly consistent with the theoretical literature. Portfolio theory models have generally proposed an explanation for cross-border banking that relies on asset diversification strategies (see, among others, Buch et al., 2014a). But other theoretical contributions on cross-border banking deviate from portfolio composition models to provide alternative explanations. For instance, Ennis (2001) suggests that banks engage in cross-regional activities so as to overcome potential information problems related to geographical distance. Also, different banking and financial regulatory frameworks may explain the direction of cross-border banking (see Morrison and White, 2009; Acharya, 2003). In particular, Houston et al. (2012) shows that banks prefer to transfer funds to markets with fewer regulations, but this is more true if the laxer regulation of the recipient country is mitigated by stronger property and creditor rights. Recently, Niepmann (2015) has proposed an alternative framework in which financial transactions, in terms of both assets and liabilities, are the endogenous outcome of two sources of country heterogeneity:

\footnotetext{
${ }^{2}$ These include the volume of bilateral phone traffic, the bilateral trade in newspapers, and bilateral migration flows.
} 
differences in factor endowments and differences in the efficiency of the banking sectors. These two elements, jointly considered, can explain different banking internationalization patterns - such as international banking, global banking, and foreign sourcing - that also emerge in the estimation of a gravity equation.

However, contrary to trade gravity models, that have nowadays strong theoretical foundations (see, e.g., the seminal contribution by Anderson and van Vincoop , 2003), gravity models for financial transactions still pose substantial theoretical challenges, as shown by Okawa and van Wincoop (2012). Among the most interesting contributions, Martin and Rey (2004) and Courdacier and Martin (2006) presents a theoretical framework in which the presence of fixed costs of cross-border financial transactions avides a testable financial gravity equation, and Head and Ries (2008) obtains a similar equation under the hypothesis of information asymmetries between countries.

Our paper contributes to these strands of literature investigating the role of relative size of banks in domestic markets and its consequences in banks' ability to participate international financial markets. To our knowledge, this has not been studied before. We also provide interpretations of the results that shed light on the functioning of the lender/borrower cross-border relationships.

\section{Data}

A large number of measures have been proposed to study globalization of financial markets (see, e.g., Lane and Milesi-Ferretti, 2007, and the survey by Kose et al., 2009). However, most of them are aggregate indices providing a synthetic measure of the degree of integration of one or more financial markets of a given country with the rest of the world. Since our analysis is based on the framework of gravity models, it requires information on bilateral positions of each country with respect to a set of other countries. For example, we need information on the gross value of the foreign assets (and eventually liabilities) held by UK banks in Germany, France, USA, etc.. To the best of our knowledge, the most reliable source of these information is the BIS Consolidated banking statistics database (CBS), that provides quarterly information on the outstanding amounts of total claims, international claims and local liabilities of banks for 31 BIS "lending countries" to over 100 destination countries. ${ }^{3}$ These information can be classified according to the type of risk intrinsic to the transaction, by maturity, by instrument, and also by the type of recipient sector (all sectors, banks, non bank financial institutions, government, private sector). ${ }^{4}$ To perform our analysis, we focus on international claims, which are reported on an immediate risk basis (i.e., assuming that the counterparty is

\footnotetext{
${ }^{3}$ Lending countries are Australia, Austria, Belgium, Brazil, Canada, Chile, Chinese Taipei, Denmark, Finland, France, Germany, Greece, Hong Kong SAR, India, Ireland, Italy, Japan, Korea, Luxembourg, Mexico, Netherlands, Panama, Portugal, Singapore, Spain, Sweden, Switzerland, Turkey, United Kingdom, United States.

${ }^{4}$ See Avdjiev et al. (2015) for an accurate and updated description of the BIS CBS database.
} 
the entity with whom the bank contracts to lend or borrow). We choose to focus on data on an immediate risk basis because the main focus of our analysis is on the ability of different banking systems to gain access to foreign funding, and not on how risks are distributed as a result of such activities. Besides, information on claims on an immediate risk basis are available for a larger set of countries than that on an ultimate risk basis. However, in the robustness checks Section we also verify that our results are partly confirmed when considering international claims on an ultimate risk basis (i.e., taking account of credit risk mitigants, such as collateral, guarantees and credit protection bought, that transfer the bank's credit exposure from a counterparty in one nation to another counterparty in another nation). Figure 1 presents the evolution of a two-years moving average of quarterly data on the total value of international claims between 2000 and 2013, distinguishing lending countries - those holding foreign assets - and borrowing countries - those where the lending countries hold their assets - according to their income level, following the definition of the World Bank. Both panels show a positive trend in the value of international claims until 2007, and a small reduction in the following years, but not for lower-income countries. ${ }^{5}$

Following the recent empirical literature, we estimate an augmented gravity model accounting for a number of characteristics of the countries analyzed and of their bilateral relationships. Data are from standard sources. Geographical distance and other data on bilateral relationships between country pairs (e.g., proximity, common language, common legal origin) are from the CEPII database. GDP is from the World Economic Outlook (WEO) Database. Characteristics of the financial sector are from the 2016 release of the Global Financial Development Dataset (GFDD) produced by the World Bank.

Finally, the characteristics of the distribution of banks by asset size, our key variable of analysis, are obtained using bank level information from the Bankscope data set. We select banks located in the lending and borrowing countries of the CBS sample with at least 1 billion USD of total assets. When both consolidated and unconsolidated baking statement are available, we use the latter, to avoid the potential bias caused by the fact that the consolidated statement includes also the activity of foreign subsidiaries. Banks for which we use consolidated balance sheet data represent $15 \%$ of all banks in our sample (30\% in term of total assets). Although Bankscope does not provide a full coverage of the banking sectors of some countries, its representativeness is indeed very high, and in fact it is the most widely used data base to conduct cross-country analysis on individual bank data. Despite a number of differences in how banks report the value of their total assets in individual statements and in official statistics collected by central banks, Duprey and Le (2016) show for example that, in the case of European countries, the sum of total assets of individual banks reported in Bankscope are comparable to those published by the ECB. A comparison of our data with those collected by the IMF in its Financial

\footnotetext{
${ }^{5}$ Although the BIS Consolidated banking statistics database (CBS) suffers from number of structural breaks, in our sample their size is never larger than $2 \%$ of the total value of total claims, with the only exception of the first quarter of 2009 , when it reaches $4 \%$.
} 
soundness indicators initiative show that also in the case of non-European countries the total assets of banks representativeness of the Bankscope sample is in the same order of magnitude of that in the euro area. ${ }^{6}$ The aggregate value of gross loans reported in Bankscope is also on average about $2 / 3$ of the value of private credit by deposit money banks and other financial institutions reported in the Global Financial Development Dataset (GFDD) produced by the World Bank, that is available for a larger number of the countries and years in our sample. Finally, since our measures could suffer if only a few banks were recorded by Bankscope in some countries and years, we only include in our sample those countries for which at least 10 banks are present. ${ }^{7}$

It is also important to notice that Bankscope tends to under-represent smaller banks, as we do by excluding from our sample of banks with less than 1 billion USD of total assets. However, this would affect our measures of the asymmetry of the distribution by reducing the degree of skewness, and therefore introducing a bias not in favor but against our hypothesis. It is therefore likely that with full representativeness of all banking systems in the world, that unfortunately is not available, our results would be stronger than what we find.

In our baseline specification, we use total assets to proxy the size of a bank, and we reconstruct the distribution moments on the country-year distributions: we compute the first two moments (mean and variance) and also the third asymmetry moment (skewness). A symmetric distribution has a skewness of zero, and positive values signal a longer right tail associated with a relatively few but large institutions and most of the mass with small institutions.

In the robustness checks we consider alternative measures of banks size, from gross loans, to other assets and equity. Our final sample consists of approximately 160, 000 observations on quarterly bilateral lending-borrowing (i.e. lending countryborrowing country) relationships from 2000 to the end of 2013.

More precisely, total claims are by country and are expressed as $1+$ the log of billion USD. Average bank size is expressed in million of USD. The coefficient of variation is the second moment of the distribution of bank size, and the asymmetry of bank size is measured by the skewness, the third moment of the distribution. We measure competition using the Boone index, that is the percentage change in bank's profits due to 1 percent change in marginal costs, see Boone (2008). Higher values of the Boone index indicate less bank competition. ${ }^{8}$ International Financial Restriction is an index of overall restrictions on capital movements by country and year calculated by Fernandez et al. (2015) based on IMF's Annual Report on Exchange Rate Arrangements and Restrictions. The ratio of foreign

\footnotetext{
${ }^{6}$ For example, in 2010 the ratio the sum of total assets of individual banks reported in Bankscope to that in the IMF database ranges from a bit less than $60 \%$ in Bosnia Herzegovina, to $77 \%$ in Russia, $90 \%$ in the United Kingdom, 100\% in Turkey and in the Czech Republic, to values larger than $100 \%$ in other countries.

${ }^{7}$ Our results are confirmed when the analysis is conducted on the full sample of countries and on a sample of countries for which at least 25 banks are present.

${ }^{8}$ In unreported regressions, available upon request, we have verified that we obtain similar results measuring competition with the Lerner index produced by the World Bank.
} 
banks to that of total banks by country and year is produced by the World Bank's Global financial data base. ${ }^{9}$ The absolute number of subsidiaries owned abroad by banks in each country is from Claessens and van Horen (2014). Distance is measured as $1+$ the $\log$ of the weighted distance between two countries, accounting for the within country distribution of population. Finally, Common legal origin is a dummy taking the value of 1 if a the borrowing and lending countries share a common legal origin, Common border takes the value of 1 if they share a common border, Common language is 1 if at least $9 \%$ of the population in the borrowing and lending countries speaks the same language, Former colonial relationship is 1 if the countries share a common colonizer. Table 1 reports a brief description of the variables used in the regressions and their sources.

Table 2 presents the descriptive statistics of the main variables used in the econometric analysis, distinguishing also in this case between lending and borrowing countries.

Both for lending and borrowing countries, skewness is always positive, suggesting a right-skewed bank size distribution. On average, foreign owned banks are close to $40 \%$ of all banks, although with a very high variability. The number of foreign subsidiaries owned abroad varies between 1 and over 1,000.

Table 3 presents the values of the bilateral correlation indices between the main variables used in our gravity model. The asymmetry of the distribution of bank size shows a positive and statistically significant correlation with the level of international claims, for both lending and borrowing countries, providing some preliminary evidence consistent with the hypothesis that countries with larger banks hold a higher amount of both foreign banking assets and liabilities. The asymmetry of the distribution of bank size has a statistically insignificant correlation with the Boone index. This suggests that our measure of asymmetry should not be related with competition in the banking industry.

\section{Empirical model}

The recent theoretical literature on trade gravity equations has shown that unbiased estimations require that the empirical model controls for the role of the "multilateral resistance", that accounts for the whole set of country characteristics affecting a country's overall import and export levels. Empirically, this amounts to including a full set of time-varying dummies for both origin and destination countries (see Head and Mayer (2014) for a thorough description of this issue). Of course, this poses a serious problem when one's interest is on country specific characteristics, that cannot be estimated because they are perfectly collinear with the dummies.

One way to address this well known and established empirical problem is the two-step approach of Eaton and Kortum (2002) and Head and Ries (2008), that

\footnotetext{
${ }^{9}$ Unfortunately, the ratio of total assets of foreign banks to total bank assets is available only for a smaller subset of countries in our sample; however, for these countries the correlation between these two measures is positive and highly statistically significant.
} 
imposes very weak structural assumptions on the underlying model by allowing to retrieve the fixed effects (the multilateral resistance terms) once all the standard dyadic features are netted out. According to this approach, in the first stage we estimate the following standard gravity regression on our panel data of outstanding stocks of international claims of the banks of the lending country in the borrowing country, including lending-country/quarter and borrowing-country/quarter fixed effects:

$$
\log \text { claims }_{L B t}=a_{1}+a_{L t}+a_{B t}+a_{2}(\text { bilateral characteristics })_{L B t}+\varepsilon_{L B t}
$$

where the dependent variable is the logarithm of international claims between (the banks of) the lending country $L$ and the borrowing country $B$ in quarter $t$; the terms $a_{L t}$ and $a_{B t}$ are the lending and borrowing countries quarter fixed effects; and $\varepsilon_{L B t}$ is the residual. In this first stage regression, we estimate the impact of standard gravity bilateral characteristics, such as the logarithm of distance, common borders, common language, etc.

Then, in the second stage, we estimate the impact of the main features of the lending and borrowing countries on the fixed effects $a_{L t}$ and $a_{B t}$. We control for countries characteristics (of the lending and borrowing country, respectively cou. char.Lt and cou. char.Bt). However, our focus is especially on the characteristics of distribution of bank size, measured by its moments, the logarithm of the mean value of each bank's total assets and by higher order moments, in particular the skewness that measures the asymmetry of the distribution (bank size mom.Lt and bank size mom.Bt). We estimate the following regressions:

$$
\begin{aligned}
& a_{L t}=b_{1}+b_{2}(\text { cou. char } \cdot L t)+b_{3}(\text { bank size mom } \cdot L t)+b_{4}(\text { time dummies })+\varepsilon_{L t} \\
& a_{B t}=b_{1}+b_{2}(\text { cou. char } \cdot B t)+b_{3}(\text { bank size mom } \cdot B t)+b_{4}(\text { time dummies })+\varepsilon_{B t}
\end{aligned}
$$

\section{Baseline results}

The top part of table 4 reports the results of the estimation of equation (1), the first stage gravity regression model, on international bank claims. To control for the potential impact of the structural breaks in the BIS Consolidated banking statistics, we have trimmed our dependent variable omitting all observations with a rate of growth above the values at the $1^{s t}$ and $99^{t h}$ percentiles of the overall distribution. Since we include quarter/lending-country and quarter/borrowing-country dummies, we can only include dyadic variables, that describe the bilateral relationship between lending and borrowing countries. After some specification search, we finally include the logarithm of the geographic bilateral distance, and four dummies that take the value of one if: 1) a language is spoken by at least $9 \%$ of the population in both countries (Common ethno-language); 2) the two countries share a common colonizer after 1945 (Common colonizer); 3) the two countries share a common legal origin (Common legal origin); 4) the two countries share a common border (Contiguity). The $R^{2}$ of the regression of 0.268 , that is high for a panel data 
regression, is explained by the large number of dummies included in the specification. Reassuringly, we have verified that the fixed effects estimated using slightly different specifications of the first stage gravity regression model are very similar, with bilateral correlations around 0.99 .

Although the main reason of the first stage is to obtain the multilateral resis- borrowing and lending tance terms, it is comforting to notice that all the regressors have the expected and countries fixed effects statistically significant signs. As it is standard in all gravity models, the logarithm of geographical distance has a negative and highly statistical significant coefficient, implying that banks tend to have a lower amount of foreign claims in countries that are farther away. Consistent with the literature, also the coefficients of the dummies for countries sharing similar characteristics are positive and statistically significant.

Having obtained the coefficients of the quarter/country dummies from the first stage equation, we have then estimated the two second stage equations, respectively for lending and borrowing countries. Since country specific characteristics are only available at the year frequency, we have used in the second stage the yearly averages of the quarterly dummies. Depending on the different specification, we end up with a bit more than 600 country/year observations. As an additional caution against the possibility that our results may be influenced by some extreme observations, we have trimmed the fixed effects that we use as the dependent variable in the second stage regression at the $1^{\text {th }}$ and $99^{\text {th }}$ percentiles. ${ }^{10}$ All our specifications include as explanatory variables: a) the GDP level of the country, consistent with the standard gravity equations model; b) the ratio of bank total assets to GDP, to proxy for the degree of development of the banking sector; c) an index of the restrictions to international capital movements; d) the ratio of the number of foreign banks to total banks in the country; e) the number of foreign subsidiaries owned by banks chartered in the country; f) the average size of banks measured by total assets (first moment); g) the coefficient of variation of the size of banks measured by total assets (second moment); and h) the skewness of the distribution of the size of banks by total assets (third moment). In addition, to capture the impact on bank's international asset holdings of the degree of competition of each country's banking sector, that indeed could be otherwise captured by the skewness, our measure of the asymmetry of the distribution of the size of banks by total assets, and the key object of our analysis, we have included the Boone index of competition in the country's banking industry (that take higher values for lower levels of competitiveness). All specifications also include year dummies. Reported standard errors are calculated using White's robust methodology.

Panel 1 of the bottom part of table 4 reports the results of the estimation of equation (2) for lending countries, i.e. countries with claims abroad. The $R^{2}$ of the regression is 0.548 . Surprisingly, we find that the size of the country and the degree of development of the banking sector have a statistically insignificant impact on the value of foreign claims. On the contrary, the presence of restrictions to international

\footnotetext{
${ }^{10}$ Reassuringly, the coefficients obtained from estimates on the whole sample from the first and second stage regressions are very similar.
} 
capital movements and the incidence of multinational banking activities have a robust statistically significant impact on bank foreign claims. As expected, banks located in countries where stronger restrictions are imposed to international capital movements have fewer cross-border claims. Countries whose banks own a larger number of foreign bank subsidiaries lend less and borrow more from abroad. Those where the share of total assets owned by foreign banks is larger are also larger international lenders and borrowers.

Coming to the characteristics of the distribution of banks by size, the coefficient of the average size of banks by total assets is positive, as expected, and statistically significant at the $1 \%$ level in both our specifications. Higher dispersion, measured by the coefficient of variation, has a negative impact on the value of international claims, although the coefficient is statistically significance only in the case of lending countries. On the contrary, we find evidence that the asymmetry of the distribution, measured by skewness, has a positive impact on bank international claims, suggesting that countries with few large "national champions" acquire more claims abroad. However, also in this case the statistical significance of the estimated coefficient is weak. Finally, we find no evidence that the degree of competition in the banking sector impacts on its internationalization towards foreign markets.

Panel 2 of the bottom part of table 4 reports the results of the estimation of equation (3) for borrowing countries, i.e. countries where banks hold foreign claims. The $R^{2}$ of the regression is 0.695 .

The picture emerging from the analysis of borrowing countries is partly different from that of lenders. Consistent with the literature on gravity equation models, the logarithm of the country's GDP has in this case a positive and statistically significant coefficient, providing some evidence that banks are more likely to hold foreign claims in larger countries. The degree of development of the banking sector has instead an economically and statistically insignificant impact. As expected, and as in the case of lending countries, the coefficient of the index of restrictions to international capital movements is negative and statistically significant, suggesting that foreign banks are less likely to invest in countries where international capital movements are more restricted. More interestingly, and different from what found in the case of lenders, the presence of multinational banks has a positive impact on the amount of funding that a country obtains from abroad. Countries that own a larger number of foreign subsidiaries and that host a larger share of foreign banks obtain a higher amount of financing from overseas.

Coming to the characteristics of the distribution of bank size by total assets, the focus of our analysis, Panel 2 of the bottom part of table 4 shows that countries where banks are on average larger attract a higher amount of foreign claims, as shown by the positive and highly significant coefficient. The coefficient of variation has an insignificant impact, as shown by the negative and statistically insignificant coefficient. Interestingly, the skewness, measuring the asymmetry of the distribution of banks' asset in the borrowing country, has a positive coefficient, statistically significant at the $5 \%$ level. Reassuringly, the degree of competition in the banking 
industry has a statistically insignificant effect. ${ }^{11}$

The impact of the characteristics of the distribution of banks by size on international bank claims is not only statistically significant, but also economically relevant. A change from the value at the $25^{t h}$ percentile to that at the $75^{t h}$ percentile of the distribution across countries of average bank size causes an increase of about $40 \%$ in the level of international claims for lenders and $20 \%$ for borrowers. An identical change in the value of the skewness has an impact of $7 \%$ for lenders and $5 \%$ for borrowers, the same order of magnitude as that of the coefficient of variation, that is $8 \%$ for lenders and $2 \%$ for borrowers.

Overall, our results suggest that countries with dual banking system, in which some large banks coexist with a larger number of smaller credit intermediaries, are more integrated within the international financial markets: as seen above they lend more abroad, and they obtain more funding from abroad. And this holds true controlling for the presence of multinational banks as well as for the degree of competition in the banking industry. In other words, even after controlling for average bank size, countries hosting some very large banks are more integrated in the world financial markets. Large "national champions" stand out in dualistic banking systems and are more capable of lending and, especially, of raising funds abroad, possibly also acting as hubs for smaller domestic banks, as discussed more extensively in the Introduction. ${ }^{12}$

\section{Robustness checks}

Our baseline results show that the skewness of the distribution of banks by asset size has a significant role in explaining bank foreign claims. In this section we refine our analysis considering four different dimensions. First, we focus on the degree of development of the different countries. It is a well known fact that financial development and international financial integration are increasing functions of the income level of a country, a fact that is clear also from figure 1. For this reason, we replicate our analysis considering only the subsample of high income countries, according to the definition of the World Bank. We expect that this might have an impact on our results if the fixed costs of acquiring foreign claims are lower within

\footnotetext{
${ }^{11}$ Although Barba Navaretti et al. (2010) provide evidence that at the aggregate local claims in foreign currency of foreign affiliates are of very limited relevance, this may not be the case for some emerging and developing countries like Ecuador, El Salvador and Panama, that are fully dollarized, or others where the levels of foreign-currency denominated domestic loans is very high, such as Bolivia, Peru, Uruguay, Bulgaria and Hungary. To check that our results are not affected by the role of local claims in foreign currencies, we have estimated our model excluding all the countries listed above. Reassuringly, the results are broadly unchanged. We thank an anonymous reviewer for pointing out this potentially very relevant issue.

${ }^{12}$ Affinito and Pozzolo (2017) provide some evidence confirming that banks more active in the international markets are also more interconnected within the domestic interbank market.
} 
the set of more developed economies. Second, we distinguish the periods before and after the 2007-2008 financial crisis, that had a substantial impact especially on international financial transactions. Third, we calculate the moments of the distribution of bank size on other measures than total assets: equity, other earning assets, and loans. Fourth, instead of considering the value of international claims owned by banks towards all foreign sectors abroad, we limit our analysis to international claims towards banks. Finally, we replicate our analysis considering the value of international claims on an ultimate risk basis, rather than on the immediate risk basis. With some caveats, the results of the robustness checks confirm those of our baseline specification.

\subsection{Country development}

The top part of table 5 reports the results of first stage regression for the subsample of high income countries, both on the side of lending and borrowing countries, that includes just above 56,000 observations. The $R^{2}, 0.280$. Within the subset of most developed countries, geographical distance and sharing a common legal origin do not have a statistically significant impact on the amount of bilateral claims held by banks. This is not entirely surprising, considering the sizable amount of financial linkages among the world most important financial centers (London, New York and Tokyio), that indeed benefit from covering geographical areasthat are very far away from each other. Among this set of countries, proximity is not a good proxy for the ability to collect information, neither the differences among the legal systems, most likely because they are in all instances very advanced.

The results of the second stage regression for the lending countries, reported in Panel 1 of the bottom part of table 5, broadly confirms the picture obtained form the full sample, but with some differences. In particular, the coefficients of the size of the country and of its banking market are not statistically significant, neither is significant the coefficient of the number of banks owned abroad. The presence of restrictions to international capital movements and the incidence of multinational banking activities have instead a statistically significant impact on bank international claims also in this smaller sample. Also the characteristics of the distribution of banks by size have a very similar effect to that estimated on the whole sample: the coefficient of the average size of banks by total assets is positive, as expected, and statistically significant at the $1 \%$ level. Higher dispersion, measured by the coefficient of variation, has a negative impact on the value of international claims, although statistically insignificant, while the asymmetry of the distribution, measured by skewness, has a positive impact on bank international claims, that is also statistically insignificant.

Panel 2 of the bottom part of table 5 presents the results for the borrowing countries. The picture that emerges in this case is even more similar to that obtained form the full sample. The only difference is the lack of significance of the coefficients of the index of international financial restrictions, that is likely to be due to the limited variability in capital restrictions within high income countries. Reassuringly, the coefficients of the average size of banks and, especially, of the 
skewness are positive and statistically significant at the $1 \%$ level in both specifications. Even among more developed countries, hosting some very large banks increases the ability to attract foreign claims. At the same time, also within this sample, all the measures of the degree of competition in the banking industry have a statistically insignificant effect.

\subsection{Before and after the financial crisis}

As already mentioned, the 2007-2008 financial crisis had a substantial impact on international bank claims. For example, Buch et al. (2014b) presents evidence of a contraction in the level of assets of foreign affiliates of German banks, and Bouvatier and Delatte (2015) further confirms the financial disintegration process that occurred within the Eurozone during the financial crises.

To verify the robustness of our results on the role of the asymmetry of the distribution of bank size in explaining the level of international claims to the crisis events, we have estimated our model separately for the years 2000-2006, before the financial crisis, and for the years 2009-2013. ${ }^{13}$ The top part of table 6 shows that the bilateral determinants of international bank claims have a similar effect in the two sub-periods, although the size of the coefficients suggests that the impact of country differences might have been stronger after the financial crisis, with the only exception of sharing a common border.

Coming to the second-stage regressions, in the case of the lending countries, Panels 1 and 2 of the bottom part of table 6 show that the results are very similar to those of the regression on the full sample. Reassuringly, the coefficients of skewness is positive and statistically significant in all our specifications, for both lending and borrowing countries. This provides additional evidence in support of our claim that dual banking systems are more integrated within the international financial system.

Panels 3 and 4 of the bottom part of table 6 show instead that the financial crisis caused a major turmoil also in the determinants of bank foreign holdings. In fact, very few of the estimated coefficients are statistically significant. Most interesting, from the perspective of our research, the coefficients of the measure of the asymmetry of the distribution are smaller in size and they are not statistically significant, consistent with the view that the partial retrenchment and the higher volatility of foreign claims shown in figure 1 was partly related to the role of larger banks in borrowing countries.

\subsection{Alternative size measures}

An additional issue with our baseline analysis is the measure of bank size distribution. Although larger banks typically have more loans, more assets different from loans, and larger equity, the relationship between these balance sheet items and total assets is far from linear. For this reason we have estimated the second

\footnotetext{
${ }^{13}$ Results are broadly identical extending the subsamples to include the crisis period, considering the years 2000-2007 and 2008-2013.
} 
stage regressions of equations (2) and (3) calculating the first, second and third moments of the distribution of bank by the size of the gross loans, of total value of other assets different from loans, and of the value of equity.

In the case of lending countries, panels 1-3 of table 7 show a picture broadly consistent with our previous analysis. The most striking difference being the strong statistical significance of the size of the country and the development of its banking sector. As to the measures of the asymmetry of the distribution of banks by the three asset classes considered, none of them has a statistically significant impact on the amount if international claims held by banks abroad. On the contrary, for borrowing countries, panels 4-6 of table 7 confirm a positive and statistically significant impact on claims held by foreign banks of the asymmetry of the distribution calculated on all three alternative measures of the distribution of bank size.

\subsection{International claims to banks}

Our previous results suggest that the asymmetry of the distribution of banks by size is relevant especially in the case of borrower countries, suggesting that international investors look for safe and possibly too-big-to fail foreign counterparts. If this is the case, our results should be confirmed also focusing specifically on international claims to banks, instead of the broader category of international claims to all sectors.

The top part of table 8 presents the results of the first stage regression, estimated on just above 93,000 observations, with an $R^{2}$ of 0.630 . The bilateral determinants of international claims to banks are very similar to those of the international claims to all sectors.

The results of the second-stage regressions present some dissimilarities with respect to those on international bank claims towards all sectors of economic activity. Panels 1 and 2 of the bottom part of table 8 show that the coefficients of the size of the country are positive and statistically significant for both lenders and borrowers. A more developed banking market, proxied by a higher ratio of bank assets to GDP, has instead a negative impact on the amount of international claims for lending countries, but a positive coefficient for borrowing countries. Of the two measures of the internationalization of the banking industry, only the number of subsidiaries owned abroad has a positive significant impact in the case of borrowing countries. Coming to our variable of interest, the asymmetry of the distribution of banks by total assets only has a statistically significant impact on the amount of claims held by foreign banks in the borrowing countries, confirming that large banks are better at attracting foreign funding.

\subsection{Ultimate risk basis}

Our last robustness check relates to the type of risk assumed by banks. BIS data on bank international claims are available on an immediate risk basis and on an ultimate risk basis. The former, that we have used in the analysis presented so far, allocate each position "to the primary party to a contract". The latter allocate 
instead each position "to a third party that has contracted to assume the debts or obligations of the primary party if that party fails to perform". In this case, claims are therefore allocated to the country and sector of the entity that guarantees them (for example, in the case of claims on branches, the country of the parent bank).

Since it may well be the case that the geographical pattern of bank foreign claims on an ultimate risk basis differs significantly from that on an immediate risk basis, we have estimated all three equations (1), (3) and (2) on data on an ultimate risk basis.

The top part of table 9 reports the results of the first stage estimates. The number of observations is in this case just above 136,000 and the $R^{2}$ is 0.615 . The results are similar to those obtained from the regression on claims on an immediate risk basis, with the exception of the coefficient for countries sharing a common legal system, that is in this case negative and statistically significant. This difference suggests that some of the claims on an immediate basis are granted by entities located in other countries.

The estimates of the second stage regression provide some interesting additional insights with respect to the evidence emerging from the analysis if the claims on an immediate risk basis. Panel 1 of the bottom part of table 9 shows that larger countries are more likely to hold foreign claims on an ultimate risk basis, while the development of the banking sector has no significant impact. As expected, restrictions on foreign capital movements have instead a negative impact on the value of foreign claims. Contrary to the case of claims on immediate risk basis, focusing on ultimate risk we find that a larger number of foreign owned subsidiaries has a negative effect on the share of international claims held in borrowing countries, suggesting that foreign subsidiaries are used for funding, but not for risk transfer.

What is most interesting is the significant impact of all three dimensions of the distribution of banks by asset size: foreign lending on an ultimate risk basis is more common for countries where the average size of banks is larger, the dispersion is lower and the asymmetry of the distribution is stronger. Our evidence suggests therefore that large "national champions" provide a larger amount of risk coverage abroad. Finally, the coefficient of the Boone index is positive and statistically significant, but does not alter the significance of our other coefficients of interest.

Panels 3 and 4 of the bottom part of table 9 also provide a rather different picture form that obtained from the analysis of claims on an immediate risk basis. Larger countries and those with more developed banking sectors are more likely to hold foreign claims on an ultimate risk basis, the restrictions on foreign capital movements have as expected a negative impact on the value of foreign claims, and the presence of foreign banks increases the likelihood of being granted risk coverage. What is less obvious is that countries that hold a larger number of subsidiaries abroad are less likely to be granted risk coverage. Finally, the coefficient of the skewness of the distribution of banks by total assets is not statistically significant, suggesting that large "national champions" are more likely to obtain funding, but not to obtain risk coverage from abroad. 


\subsection{The role of foreign banks}

Finally, since the presence of foreign banks can be a crucial issue affecting our analysis, in addition to controlling for its direct effect, we have also verified whether it impacts on the relationship between the skewness of the distribution of bank size. To this aim, we have included in the baseline specification the interaction of the share of foreign banks and of the number of banks owned abroad with the skewness of the distribution of banks by total assets. ${ }^{14}$

The results, reported in table 10, show that the presence of foreign banks dampens the impact of the skewness of the distribution of banks by asset size on the value of international claims. Indeed, the negative coefficients of the interaction terms estimated in three of the four cases considered imply that a direct presence of foreign banks is a substitute in international transactions to having larger banks. Reassuringly, for the entire set of values of foreign bank presence in our sample, the marginal effect of the skewness of the distribution remains economically and statistically significant.

\section{Conclusions}

Building on the standard framework of gravity regression models, we have estimated the relationship between the distribution of bank asset size on a country's propensity to engage in international banking. Our results confirm that crossborder bank linkages are explained by the variables normally considered in the gravity literature, such as country size and distance, but that they are also related to measures of the asymmetry of the distribution of banks' size. In particular, countries with a dual banking system, where a small number of very large banks, the so-called "national champions", coexist with a large number of smaller banks, are more integrated within the international financial system. Such integration comes both from a higher amount of claims held abroad and, to a larger extent, from a higher amount of foreign liabilities.

This pattern is robust as it is also confirmed when controlling for the degree of competition in the banking industry, suggesting that the asymmetry of the distribution does not proxy for market concentration, and for the presence of multinational banks. Our findings are consistent with a dual banking system in which large banks clearly stand out as financial partners in international capital markets.

These banks face a lower incidence of the fixed costs and, what is more, act as hubs for smaller, domestic banks. They are notable also because of too-big-tofail expectations. In fact, on the one hand, lending to a country is likely to be safer when a few large banks clearly stand out as too-big-too fail. On the other hand, countries with few very large banks are more likely to provide risk coverage to other countries, as it emerges from the analysis of the data on an ultimate risk basis, because these financial intermediaries have a stronger incentive to take o risk since they perceive themselves as too-big-to-fail. Consistent with this interpretation, our

${ }^{14}$ We thank an anonymous reviewer also for this interesting suggestion. 
findings are confirmed by a number of robustness checks, and, at the same time, they are not confirmed for the period following the global financial crisis of 20072008. Our effect of a dualistic banking system vanished when even the large banks stopped perceiving themselves and being perceived as too-big-to-fail, and a large number of idiosyncratic shocks have increased the variability of bank cross-border claims.

To the best of our knowledge, our analysis is the first to focus on the impact of the distribution of banks by asset size on the internationalization of the banking sector. In this sense, we extend the insights on the impact of firm size on international trade flows and FDIs in the manufacturing sector recently found by (Barba Navaretti et al. , 2015, and Pietrovito et al., 2013) to the cross-border activities of banks. Our results have straightforward but important policy implications, confirming that larger banks have a disproportionally higher impact on financial globalization, therefore being a channel for both risk diversification opportunities and, yet, higher risks of contagion. 
Evolution of International claims

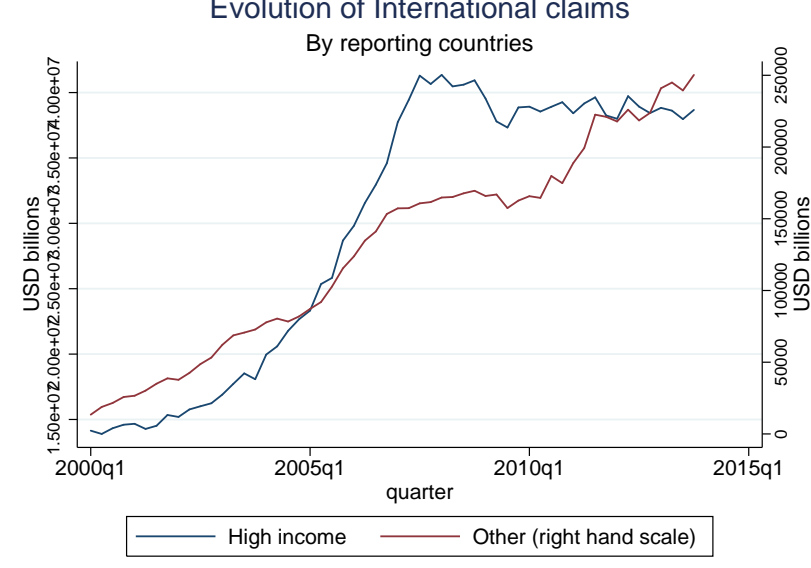

(a) lending

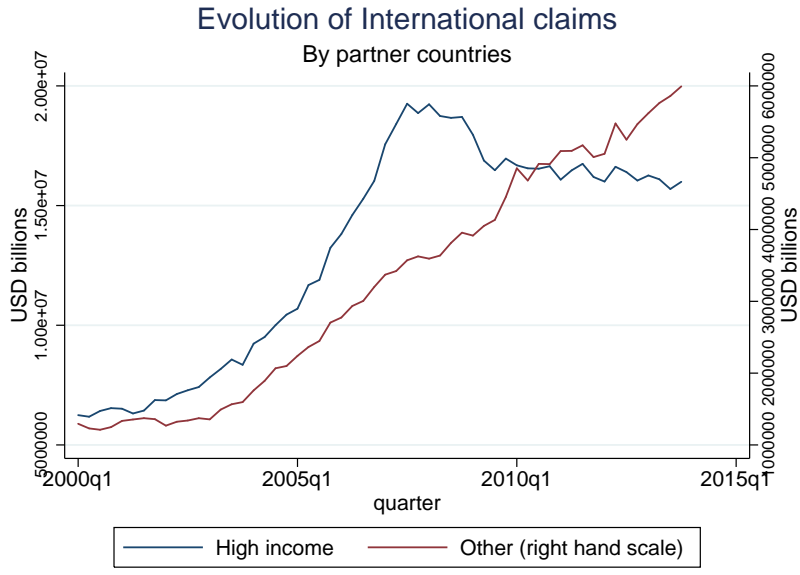

(b) borrowing

Figure 1: International claims by country groups 


\begin{tabular}{|c|c|c|}
\hline Name & Description & Source \\
\hline Total claims & Annual average of quarterly values of international claims by country and year $(1+\log )$. & BIS Consolidated banking statistics \\
\hline Average bank size $(\log )$ & Average value of total assets of the banks by country and year $(1+\log )$. & Bankscope \\
\hline Dispersion of bank size & Coefficient of variation of the distribution of total assets of the banks by country and year & Bankscope \\
\hline Skewness of bank size & Skeweness of the distribution of total assets of the banks by country and year & Bankscope \\
\hline GDP $(\log )$ & Gross domestic product by country and year $(\log )$ & IMF, World Economic Outlook \\
\hline Competition (Boone index) & $\begin{array}{l}\text { Elasticity of bank profits to bank marginal costs by country and year; } \\
\text { an increase implies lower competition } \\
\text { and marginal costs by country and year; an increase implies lower competition }\end{array}$ & World Bank, Global financial data base \\
\hline Foreign banks (share) & Ratio of the number of foreign banks to that of total banks by country and year & World Bank, Global financial data base \\
\hline Banks owned abroad (no.) & Number of subsidiaries owned abroad by banks in the country & (Claessens and van Horen (2014)) \\
\hline International fin. restr. & Index of overall restrictions on capital movements by country and year & Fernandez et al. (2015) \\
\hline Bank assets/GDP & Value of total bank assets over GDP by country and year & World Bank, Global financial data base \\
\hline Distance $(\log )$ & Weighted bilateral distance between lending and borrowing countries (log.) & CEPII database (Mayer and Zignago (2011)) \\
\hline Common legal origin & Dummy taking the value of 1 if in the lending and borrowing countries share a common legal origin & CEPII database (Mayer and Zignago (2011)) \\
\hline Common border & Dummy taking the value of 1 if the lending and borrowing countries share a common border & CEPII database (Mayer and Zignago (2011)) \\
\hline Common language & $\begin{array}{l}\text { Dummy taking the value of } 1 \text { if in the lending and borrowing countries a common language is spoken } \\
\text { by at least } 9 \% \text { of the population }\end{array}$ & CEPII database (Mayer and Zignago (2011)) \\
\hline Common colonizer & Dummy taking the value of 1 if the lending and borrowing countries share a common colonizer & CEPII database (Mayer and Zignago (2011)) \\
\hline
\end{tabular}

Table 1: List of the variables used in the regressions 


\begin{tabular}{|c|c|c|c|c|c|c|}
\hline & Obs. & Mean & Coeff. var. & Median & p10 & p90 \\
\hline & \multicolumn{6}{|c|}{ Lending countries } \\
\hline Total claims $(1+\log )$ & 2,395 & 78.84 & 3.52 & 0.00 & 0.00 & 215.12 \\
\hline Mean of bank size & 1,166 & 17.40 & 1.77 & 6.62 & 1.79 & 45.60 \\
\hline Dispersion of bank size & 1,077 & 1.23 & 0.83 & 0.94 & 0.24 & 2.78 \\
\hline Skewness of bank size & 1,073 & 1.86 & 1.14 & 1.16 & 0.00 & 4.93 \\
\hline GDP $(1+\log )$ & 1,840 & 4.67 & 0.40 & 4.64 & 2.44 & 7.19 \\
\hline Competition (Boone index) & 1,857 & -0.07 & -1.94 & -0.06 & -0.18 & 0.04 \\
\hline Foreign banks (share) & 1,739 & 38.17 & 0.72 & 37.00 & 1.00 & 78.00 \\
\hline Banks owned abroad (no.) & 2,395 & 678.65 & 4.22 & 1.06 & 0.00 & 1052.67 \\
\hline International fin. restr. & 1,380 & 0.35 & 0.95 & 0.20 & 0.00 & 0.85 \\
\hline Distance $(\log )$ & 2,293 & 8.62 & 0.08 & 8.74 & 7.96 & 9.23 \\
\hline Common legal origin & 2,293 & 0.31 & 1.04 & 0.27 & 0.00 & 1.00 \\
\hline Common border & 2,293 & 0.01 & 3.67 & 0.00 & 0.00 & 0.04 \\
\hline Common language & 2,293 & 0.26 & 1.28 & 0.11 & 0.00 & 1.00 \\
\hline Common colonizer & 2,293 & 0.13 & 1.80 & 0.00 & 0.00 & 0.43 \\
\hline \multirow[t]{2}{*}{ Number of banks } & 2,128 & 83.48 & 3.71 & 17.00 & 3.00 & 127.00 \\
\hline & \multicolumn{6}{|c|}{ Borrowing countries } \\
\hline Total claims $(1+\log )$ & 2,912 & 64.84 & 1.23 & 30.78 & 1.39 & 179.42 \\
\hline Mean of bank size & 1,192 & 17.20 & 1.78 & 6.50 & 1.75 & 45.60 \\
\hline Dispersion of bank size & 1,089 & 1.22 & 0.83 & 0.93 & 0.24 & 2.78 \\
\hline Skewness of bank size & 1,085 & 1.84 & 1.14 & 1.16 & 0.00 & 4.90 \\
\hline GDP $(1+\log )$ & 1,999 & 4.43 & 0.45 & 4.36 & 2.06 & 7.10 \\
\hline Competition (Boone index) & 1,982 & -0.07 & -1.91 & -0.06 & -0.18 & 0.04 \\
\hline Lerner index & 1,684 & 0.27 & 0.55 & 0.26 & 0.12 & 0.44 \\
\hline Foreign banks (share) & 1,808 & 38.23 & 0.72 & 37.00 & 1.00 & 78.00 \\
\hline Banks owned abroad (no.) & 2,912 & 173.13 & 3.95 & 0.00 & 0.00 & 285.80 \\
\hline International fin. restr. & 1,400 & 0.36 & 0.93 & 0.23 & 0.00 & 0.85 \\
\hline Distance $(\log )$ & 2,730 & 8.63 & 0.06 & 8.77 & 7.75 & 9.21 \\
\hline Common legal origin & 2,730 & 0.28 & 0.62 & 0.32 & 0.00 & 0.45 \\
\hline Common border & 2,730 & 0.02 & 2.14 & 0.00 & 0.00 & 0.07 \\
\hline Common language & 2,730 & 0.18 & 1.02 & 0.16 & 0.00 & 0.43 \\
\hline Common colonizer & 2,730 & 0.09 & 1.05 & 0.07 & 0.00 & 0.19 \\
\hline Number of banks & 2,393 & 74.33 & 3.94 & 13.00 & 2.00 & 117.00 \\
\hline
\end{tabular}

Variables are defined in table 1

Table 2: Descriptive statistics 


\begin{tabular}{|c|c|c|c|c|c|c|c|c|c|c|c|c|c|c|c|}
\hline & \multicolumn{15}{|c|}{ Lending countries } \\
\hline & 1 & 2 & 3 & 4 & 5 & 6 & 7 & 8 & 9 & 10 & 11 & 12 & 13 & 14 & 15 \\
\hline 1 Total claims $(1+\log )$ & 1.00 & & & & & & & & & & & & & & \\
\hline 2 Mean of bank size & $0.37^{*}$ & 1.00 & & & & & & & & & & & & & \\
\hline 3 Dispersion of bank size & $0.56^{*}$ & $0.63^{*}$ & 1.00 & & & & & & & & & & & & \\
\hline 4 Skewness of bank size & $0.52^{*}$ & $0.48^{*}$ & $0.94^{*}$ & 1.00 & & & & & & & & & & & \\
\hline 5 GDP $(1+\log )$ & $0.38^{*}$ & $0.39^{*}$ & $0.68^{*}$ & $0.66^{*}$ & 1.00 & & & & & & & & & & \\
\hline 6 Competition (Boone index) & -0.03 & 0.05 & 0.08 & 0.04 & 0.02 & 1.00 & & & & & & & & & \\
\hline 7 Foreign banks (no.) & $-0.22^{*}$ & $-0.05^{*}$ & $-0.24^{*}$ & $-0.27^{*}$ & $-0.40^{*}$ & -0.04 & 1.00 & & & & & & & & \\
\hline 8 Banks owned abroad (no.) & $0.58^{*}$ & $0.39^{*}$ & $0.76^{*}$ & $0.72^{*}$ & $0.53^{*}$ & $-0.23^{*}$ & 1.00 & & & & & & & & \\
\hline 9 International fin. restr. & $-0.28^{*}$ & $-0.24^{*}$ & $-0.36^{*}$ & $-0.29^{*}$ & $0.06^{*}$ & 0.04 & $-0.15^{*}$ & $-0.25^{*}$ & 1.00 & & & & & & \\
\hline 10 Distance $(\log )$ & $-0.04^{*}$ & -0.04 & -0.05 & -0.01 & $-0.09^{*}$ & $0.11^{*}$ & $-0.10^{*}$ & -0.04 & $0.13^{*}$ & 1.00 & & & & & \\
\hline 11 Common legal origin & -0.04 & 0.05 & -0.02 & -0.04 & $-0.22^{*}$ & -0.02 & $0.14^{*}$ & 0.03 & 0.03 & $0.06^{*}$ & 1.00 & & & & \\
\hline 12 Common border & $0.10^{*}$ & 0.02 & $0.17^{*}$ & $0.18^{*}$ & $0.26^{*}$ & $0.05^{*}$ & 0.02 & $0.13^{*}$ & $-0.10^{*}$ & $-0.24^{*}$ & $-0.08^{*}$ & 1.00 & & & \\
\hline 13 Common language & $-0.12^{*}$ & -0.02 & $-0.09^{*}$ & $-0.09^{*}$ & $-0.35^{*}$ & 0.03 & $0.25^{*}$ & $-0.05^{*}$ & $-0.13^{*}$ & $0.23^{*}$ & $0.55^{*}$ & $-0.14^{*}$ & 1.00 & & \\
\hline 14 Common colonizer & $-0.08^{*}$ & -0.01 & $-0.09^{*}$ & $-0.10^{*}$ & $-0.28^{*}$ & 0.02 & $0.13^{*}$ & 0.01 & 0.01 & $0.13^{*}$ & $0.53^{*}$ & $-0.12^{*}$ & $0.49^{*}$ & 1.00 & \\
\hline \multirow[t]{3}{*}{15 Number of banks } & $0.40^{*}$ & $0.19^{*}$ & $0.56^{*}$ & $0.57^{*}$ & $0.44^{*}$ & 0.02 & $-0.15^{*}$ & $0.75^{*}$ & $-0.13^{*}$ & -0.00 & -0.04 & $0.12^{*}$ & -0.03 & $-0.07^{*}$ & 1.00 \\
\hline & \multicolumn{15}{|c|}{ Borrowing countries } \\
\hline & 1 & 2 & 3 & 4 & 5 & 6 & 7 & 8 & 9 & 10 & 11 & 12 & 13 & 14 & 15 \\
\hline 1 Total claims $(1+\log )$ & 1.00 & & & & & & & & & & & & & & \\
\hline 2 Mean of bank size & $0.54^{*}$ & 1.00 & & & & & & & & & & & & & \\
\hline 3 Dispersion of bank size & $0.82 *$ & $0.64^{*}$ & 1.00 & & & & & & & & & & & & \\
\hline 4 Skewness of bank size & $0.76^{*}$ & $0.49^{*}$ & $0.94^{*}$ & 1.00 & & & & & & & & & & & \\
\hline 5 GDP $(1+\log )$ & $0.68^{*}$ & $0.39^{*}$ & $0.68^{*}$ & $0.66^{*}$ & 1.00 & & & & & & & & & & \\
\hline 6 Competition (Boone index) & 0.02 & 0.05 & $0.08^{*}$ & 0.04 & 0.01 & 1.00 & & & & & & & & & \\
\hline 7 Foreign banks (no.) & $-0.13^{*}$ & -0.05 & $-0.24^{*}$ & $-0.26^{*}$ & $-0.39^{*}$ & -0.05 & 1.00 & & & & & & & & \\
\hline 8 Banks owned abroad (no.) & $0.66^{*}$ & $0.38^{*}$ & $0.76^{*}$ & $0.72^{*}$ & $0.53^{*}$ & $0.06^{*}$ & $-0.23^{*}$ & 1.00 & & & & & & & \\
\hline 9 International fin. restr. & $-0.31^{*}$ & $-0.24^{*}$ & $-0.36^{*}$ & $-0.30^{*}$ & 0.04 & 0.03 & $-0.13^{*}$ & $-0.25^{*}$ & 1.00 & & & & & & \\
\hline 10 Distance $(\log )$ & $-0.33^{*}$ & $-0.07^{*}$ & $-0.19^{*}$ & $-0.16^{*}$ & $-0.15^{*}$ & $0.07^{*}$ & -0.03 & $-0.17^{*}$ & $0.14^{*}$ & 1.00 & & & & & \\
\hline 11 Common legal origin & $-0.08^{*}$ & $0.10^{*}$ & $0.12^{*}$ & $0.10^{*}$ & $-0.17^{*}$ & $0.13^{*}$ & 0.02 & $0.15^{*}$ & $-0.11^{*}$ & $0.34^{*}$ & 1.00 & & & & \\
\hline 12 Common border & $0.49^{*}$ & $0.18^{*}$ & $0.53^{*}$ & $0.51^{*}$ & $0.28^{*}$ & -0.01 & $-0.05^{*}$ & $0.47^{*}$ & $-0.28^{*}$ & $-0.51^{*}$ & $-0.11^{*}$ & 1.00 & & & \\
\hline 13 Common language & $-0.16^{*}$ & $0.10^{*}$ & $0.09^{*}$ & $0.07^{*}$ & $-0.24^{*}$ & $0.07^{*}$ & $0.22^{*}$ & $0.14^{*}$ & $-0.12^{*}$ & $0.42^{*}$ & $0.30^{*}$ & $-0.23^{*}$ & 1.00 & & \\
\hline 14 Common colonizer & $-0.29^{*}$ & $0.08^{*}$ & -0.02 & -0.03 & $-0.31^{*}$ & 0.03 & $0.17^{*}$ & $0.13^{*}$ & 0.02 & $0.34^{*}$ & $0.22^{*}$ & $-0.26^{*}$ & $0.50^{*}$ & 1.00 & \\
\hline 15 Number of banks & $0.48^{*}$ & $0.19^{*}$ & $0.56^{*}$ & $0.57^{*}$ & $0.43^{*}$ & $0.02^{*}$ & $-0.15^{*}$ & $0.75^{*}$ & $-0.13^{*}$ & $-0.04 *$ & -0.01 & $0.25^{*}$ & $0.06^{*}$ & $-0.07^{*}$ & 1.00 \\
\hline
\end{tabular}

Table 3: Bilateral correlations 


\begin{tabular}{lc}
\hline \hline \multicolumn{2}{c}{ First stage regression } \\
\hline \hline Distance $(\log )$ & International claims $(\log )$ \\
& $-0.059^{* * *}$ \\
Common language & $(0.004)$ \\
& $0.062^{* * *}$ \\
Common colonizer & $(0.009)$ \\
& $0.089^{* * *}$ \\
Common legal origin & $(0.012)$ \\
& 0.007 \\
Common border & $(0.006)$ \\
& $0.129^{* * *}$ \\
\hline$R^{2}$ & $(0.016)$ \\
Obs. & 0.268 \\
\hline
\end{tabular}

\begin{tabular}{lcc}
\hline \hline \multicolumn{3}{c}{ Second stage regression } \\
\hline \hline & Lenders' fixed effects & Borrowers' fixed effects \\
& $(1)$ & $(2)$ \\
\hline GDP $(l o g)$ & -0.004 & $0.030^{* * *}$ \\
& $(0.017)$ & $(0.007)$ \\
Bank assets/GDP & 0.000 & 0.000 \\
& $(0.000)$ & $(0.000)$ \\
International fin. restr. & $-0.338^{* * *}$ & $-0.079^{* * *}$ \\
& $(0.048)$ & $(0.022)$ \\
Foreign banks (share) & $-0.003^{* * *}$ & $0.001^{* * *}$ \\
& $(0.001)$ & $(0.000)$ \\
Banks owned abroad (no.) & $0.035^{* * *}$ & $0.013^{* * *}$ \\
& $(0.011)$ & $(0.004)$ \\
Mean of bank size $(l o g)$ & $0.210^{* * *}$ & $0.107^{* * *}$ \\
& $(0.027)$ & $(0.011)$ \\
Dispersion of bank size & $-0.109^{* *}$ & -0.009 \\
& $(0.051)$ & $(0.020)$ \\
Skewness of bank size & $0.045^{* *}$ & $0.017^{* *}$ \\
& $(0.020)$ & $(0.007)$ \\
Competition (Boone index) & -0.063 & 0.040 \\
& $(0.085)$ & $(0.030)$ \\
\hline$R^{2}$ & 0.548 & 0.695 \\
Obs. & 646 & 651 \\
\hline \hline The top part of the table presents the results of the estimation of equation $(1)$. The de- \\
pendent variable is the logarithm of the value of international bank claims of the reporting \\
country (lender) in the partner country (borrower), on an immediate risk basis. The re- \\
gression includes time*lenders and time*borrowers fixed effects. The bottom part of the \\
table presents the results of the estimation of equations $(2)$ and (3). The dependent vari- \\
ables are the time-varying time*lenders and time-borrowers fixed effects estimated from \\
equation (1). All explanatory variables are defined in table 1. Robust standard errors are \\
reported in parenthesis. ${ }^{*}$ indicates significance at 10\% level, ${ }^{* *}$ at $5 \%$ and ${ }^{* * *}$ at 1\%. \\
& & \\
& & \\
& &
\end{tabular}

Table 4: All countries 


\begin{tabular}{lc}
\hline \hline \multicolumn{2}{c}{ First stage regression } \\
\hline \hline & International claims $(\log )$ \\
\hline Distance $(\log )$ & 0.002 \\
& $(0.008)$ \\
Common language & $0.063^{* * *}$ \\
& $(0.020)$ \\
Common colonizer & $0.048^{*}$ \\
& $(0.025)$ \\
Common legal origin & -0.001 \\
& $(0.013)$ \\
Common border & $0.176^{* * *}$ \\
& $(0.025)$ \\
\hline$R^{2}$ & 0.280 \\
Obs. & 56,175 \\
\hline \hline
\end{tabular}

\begin{tabular}{lcc}
\hline \hline \multicolumn{3}{c}{ Second stage regression } \\
\hline \hline & Lenders' fixed effects & Borrowers' fixed effects \\
& $(1)$ & $(2)$ \\
\hline GDP $(l o g)$ & -0.039 & $0.028^{* * *}$ \\
Bank assets/GDP & $(0.028)$ & $(0.010)$ \\
& -0.000 & -0.000 \\
International fin. restr. & $(0.001)$ & $(0.000)$ \\
& $-0.348^{* * *}$ & 0.017 \\
Foreign banks (share) & $(0.090)$ & $(0.042)$ \\
& $-0.004^{* * *}$ & $0.001^{* * *}$ \\
Banks owned abroad (no.) & $(0.001)$ & $(0.000)$ \\
& 0.022 & $0.021^{* * *}$ \\
Mean of bank size $(\log )$ & $(0.015)$ & $(0.005)$ \\
& $0.357^{* * *}$ & $0.127^{* * *}$ \\
Dispersion of bank size & $(0.048)$ & $(0.015)$ \\
& -0.070 & -0.032 \\
Skewness of bank size & $(0.079)$ & $(0.029)$ \\
& 0.052 & $0.029^{* * *}$ \\
Competition (Boone index) & $(0.032)$ & $(0.011)$ \\
& -0.033 & 0.024 \\
$R^{2}$ & $(0.116)$ & $(0.040)$ \\
Obs. & 0.528 & 0.681 \\
\hline \hline
\end{tabular}

The top part of the table presents the results of the estimation of equation (1) on the sub-sample of high-income lending and borrowing countries, according to the definition of the World Bank. The dependent variable is the logarithm of the value of international bank claims of the reporting country (lender) in the partner country (borrower), on an immediate risk basis. The regression includes time*lenders and time*borrowers fixed effects. The bottom part of the table presents the results of the estimation of equations (2) and (3). The dependent variables are the time-varying time*lenders and time-borrowers fixed effects estimated from equation (1). All explanatory variables are defined in table 1. Robust standard errors are reported in parenthesis. ${ }^{*}$ indicates significance at $10 \%$ level, ${ }^{* *}$ at $5 \%$ and ${ }^{* * *}$ at $1 \%$.

Table 5: High income countries 


\begin{tabular}{lcc}
\hline \hline \multicolumn{3}{c}{ First stage regression } \\
\hline \hline & $2000-2006$ & $2009-2013$ \\
& $(1)$ & $(2)$ \\
\hline Distance $($ log $)$ & $-0.060^{* * *}$ & $-0.098^{* * *}$ \\
& $(0.005)$ & $(0.007)$ \\
Common language & $0.056^{* * *}$ & $0.050^{* * *}$ \\
& $(0.013)$ & $(0.017)$ \\
Common colonizer & $0.076^{* * *}$ & $0.106^{* * *}$ \\
& $(0.017)$ & $(0.022)$ \\
Common legal origin & 0.007 & 0.018 \\
& $(0.009)$ & $(0.012)$ \\
Common border & $0.147^{* * *}$ & $0.113^{* * *}$ \\
& $(0.021)$ & $(0.030)$ \\
\hline$R^{2}$ & 0.269 & 0.263 \\
Obs. & 76,200 & 63,099 \\
\hline \hline
\end{tabular}

\begin{tabular}{|c|c|c|c|c|}
\hline \multicolumn{5}{|c|}{ Second stage regression } \\
\hline & \multicolumn{2}{|c|}{ "Pre-crisis period: $2000-2006$} & \multicolumn{2}{|c|}{ Post-crisis period: $2009-2013$} \\
\hline & $\begin{array}{l}\text { Lenders' fixed effects } \\
\text { (1) }\end{array}$ & $\begin{array}{c}\text { Borrowers' fixed effects } \\
\qquad(2)\end{array}$ & $\begin{array}{l}\text { Lenders' fixed effects } \\
\text { (3) }\end{array}$ & $\begin{array}{c}\text { Borrowers' fixed effects } \\
\text { (4) }\end{array}$ \\
\hline \multirow[t]{2}{*}{ GDP $(\log )$} & -0.029 & $0.024^{* * *}$ & 0.031 & $0.055^{* * *}$ \\
\hline & $(0.023)$ & $(0.009)$ & $(0.030)$ & $(0.017)$ \\
\hline \multirow[t]{2}{*}{ Bank assets/GDP } & -0.000 & -0.000 & 0.000 & $0.001^{* *}$ \\
\hline & $(0.001)$ & $(0.000)$ & $(0.001)$ & $(0.000)$ \\
\hline \multirow[t]{2}{*}{ International fin. restr. } & $-0.269^{* * *}$ & $-0.079^{* * *}$ & $-0.453^{* * *}$ & $-0.103^{*}$ \\
\hline & $(0.054)$ & $(0.027)$ & $(0.126)$ & $(0.061)$ \\
\hline \multirow[t]{2}{*}{ Foreign banks (share) } & $-0.003^{* * *}$ & $0.001^{* * *}$ & $-0.004^{* *}$ & 0.000 \\
\hline & $(0.001)$ & $(0.000)$ & $(0.002)$ & $(0.001)$ \\
\hline \multirow[t]{2}{*}{ Banks owned abroad (no.) } & $0.051^{* * *}$ & $0.016^{* * *}$ & -0.006 & 0.011 \\
\hline & $(0.014)$ & $(0.005)$ & $(0.027)$ & $(0.009)$ \\
\hline \multirow[t]{2}{*}{ Mean of bank size $(\log )$} & $0.204^{* * *}$ & $0.126^{* * *}$ & $0.341^{* * *}$ & $0.100^{* * *}$ \\
\hline & $(0.033)$ & $(0.013)$ & $(0.066)$ & $(0.024)$ \\
\hline \multirow[t]{2}{*}{ Dispersion of bank size } & $-0.128^{* *}$ & -0.026 & -0.056 & 0.027 \\
\hline & $(0.061)$ & $(0.024)$ & $(0.116)$ & $(0.059)$ \\
\hline \multirow[t]{2}{*}{ Skewness of bank size } & $0.073^{* * *}$ & $0.026^{* * *}$ & 0.005 & 0.010 \\
\hline & $(0.026)$ & $(0.010)$ & $(0.042)$ & $(0.019)$ \\
\hline \multirow[t]{2}{*}{ Competition (Boone index) } & -0.132 & 0.009 & 0.200 & 0.007 \\
\hline & $(0.104)$ & $(0.038)$ & $(0.188)$ & $(0.109)$ \\
\hline$R^{2}$ & 0.538 & 0.678 & 0.655 & 0.766 \\
\hline Obs. & 428 & 433 & 134 & 131 \\
\hline
\end{tabular}

The top part of the table presents the results of the estimation of equation (1) separately for two sub-samples, before and after the financial crisis. The years 2007 and 2008 are excluded from the analysis. The dependent variable is the logarithm of the value of international bank claims of the reporting country (lender) in the partner country (borrower), on an immediate risk basis. The regression includes time*lenders and time*borrowers fixed effects. The bottom part of the table presents the results of the estimation of equations (2) and (3). The dependent variables are the time-varying time*lenders and time-borrowers fixed efects estinated from equation (1). All explatetory variables are defined in table 1 .

Robust standard errors are reported in parenthesis. ${ }^{*}$ indicates significance at $10 \%$ level,

${ }^{* *}$ at $5 \%$ and ${ }^{* * *}$ at $1 \%$.

Table 6: Normal and crisis times 


\begin{tabular}{|c|c|c|c|c|c|c|}
\hline \multicolumn{7}{|c|}{ Second stage regression } \\
\hline & \multicolumn{3}{|c|}{ "Lenders' fixed effects } & \multicolumn{3}{|c|}{ Borrowers' fixed effects } \\
\hline & (1) & $(2)$ & (3) & (4) & (5) & (6) \\
\hline \multirow[t]{2}{*}{ GDP $(\log )$} & $0.036^{* *}$ & $0.037^{*}$ & 0.018 & $0.042^{* * *}$ & $0.036^{* * *}$ & $0.039^{* * *}$ \\
\hline & $(0.018)$ & $(0.020)$ & $(0.019)$ & $(0.007)$ & $(0.009)$ & $(0.007)$ \\
\hline \multirow[t]{2}{*}{ Bank assets/GDP } & $0.001^{* *}$ & $0.002^{* * *}$ & $0.001^{* *}$ & $0.000^{* *}$ & $0.001^{* * *}$ & $0.000^{*}$ \\
\hline & $(0.000)$ & $(0.000)$ & $(0.000)$ & $(0.000)$ & $(0.000)$ & $(0.000)$ \\
\hline \multirow[t]{2}{*}{ International fin. restr. } & $-0.388^{* * *}$ & $-0.422^{* * *}$ & $-0.362^{* * *}$ & $-0.095^{* * *}$ & $-0.096^{* * *}$ & $-0.091^{* * *}$ \\
\hline & $(0.054)$ & $(0.058)$ & $(0.054)$ & $(0.025)$ & $(0.028)$ & $(0.024)$ \\
\hline \multirow[t]{2}{*}{ Foreign banks (share) } & $-0.004^{* * *}$ & $-0.004^{* * *}$ & $-0.003^{* * *}$ & $0.001^{* * *}$ & $0.001^{* *}$ & $0.001^{* * *}$ \\
\hline & $(0.001)$ & $(0.001)$ & $(0.001)$ & $(0.000)$ & $(0.000)$ & $(0.000)$ \\
\hline \multirow[t]{2}{*}{ Banks owned abroad (no.) } & $0.028^{* *}$ & $0.035^{* * *}$ & $0.033^{* * *}$ & $0.014^{* * *}$ & $0.025^{* * *}$ & $0.016^{* * *}$ \\
\hline & $(0.011)$ & $(0.010)$ & $(0.012)$ & $(0.004)$ & $(0.004)$ & $(0.004)$ \\
\hline \multirow[t]{2}{*}{ Mean of bank size (other) (log) } & $0.133^{* * *}$ & & & $0.066^{* * *}$ & & \\
\hline & $(0.020)$ & & & $(0.007)$ & & \\
\hline \multirow[t]{2}{*}{ Skewness of bank size (other) } & -0.005 & & & $0.010^{* * *}$ & & \\
\hline & $(0.008)$ & & & $(0.003)$ & & \\
\hline \multirow[t]{2}{*}{ Mean of bank size (equity) } & & $0.144^{* * *}$ & & & $0.094^{* * *}$ & \\
\hline & & $(0.025)$ & & & $(0.010)$ & \\
\hline \multirow[t]{2}{*}{ Skewness of bank size (equity) } & & -0.003 & & & 0.003 & \\
\hline & & $(0.007)$ & & & $(0.002)$ & \\
\hline \multirow[t]{2}{*}{ Mean of bank size (loans) } & & & $0.147^{* * *}$ & & & $0.087^{* * *}$ \\
\hline & & & $(0.023)$ & & & $(0.009)$ \\
\hline \multirow[t]{2}{*}{ Skewness of bank size (loans) } & & & 0.007 & & & $0.010^{* * *}$ \\
\hline & & & $(0.008)$ & & & $(0.003)$ \\
\hline \multirow[t]{2}{*}{ Competition (Boone index) } & -0.074 & -0.014 & -0.066 & $0.077^{* *}$ & $0.099^{* * *}$ & $0.063^{* *}$ \\
\hline & $(0.086)$ & $(0.088)$ & $(0.084)$ & $(0.033)$ & $(0.032)$ & $(0.031)$ \\
\hline$R^{2}$ & 0.518 & 0.518 & 0.523 & 0.648 & 0.655 & 0.667 \\
\hline Obs. & 590 & 571 & 615 & 595 & 574 & 620 \\
\hline
\end{tabular}

The table presents the results of the estimation of equations (2) and (3) measuring bank size according to the value of total loans, of other assets than loans, and of equity. The dependent variables are the time-varying time*lenders and time-borrowers fixed effects estimated from equation (1) on the entire sample. All explanatory variables are defined in table 1. Robust standard errors are reported in parenthesis. ${ }^{*}$ indicates significance at $10 \%$ level, ${ }^{* *}$ at $5 \%$ and ${ }^{* * *}$ at $1 \%$.

Table 7: Alternative size measures 


\begin{tabular}{lc}
\hline \hline \multicolumn{2}{c}{ First stage regression } \\
\hline \hline Distance $(\log )$ & International claims to banks $(\log )$ \\
& $-0.054^{* * *}$ \\
Common language & $(0.005)$ \\
& 0.015 \\
Common colonizer & $(0.014)$ \\
& $0.194^{* * *}$ \\
Common legal origin & $(0.017)$ \\
& $0.050^{* * *}$ \\
Common border & $(0.009)$ \\
& $0.538^{* * *}$ \\
\hline$R^{2}$ & $(0.020)$ \\
Obs. & 0.630 \\
\hline \hline
\end{tabular}

\begin{tabular}{lcc}
\hline \hline & Second stage regression & \\
\hline \hline & Lenders' fixed effects & Borrowers' fixed effects \\
& $(1)$ & $(2)$ \\
\hline GDP $(\log )$ & $0.324^{* * *}$ & $0.040^{* * *}$ \\
Bank assets/GDP & $(0.103)$ & $(0.014)$ \\
& $-0.006^{* * *}$ & $0.001^{* * *}$ \\
International fin. restr. & $(0.002)$ & $(0.000)$ \\
& $-0.655^{*}$ & $-0.112^{* * *}$ \\
Foreign banks (share) & $(0.392)$ & $(0.034)$ \\
& 0.006 & -0.000 \\
Banks owned abroad (no.) & $(0.004)$ & $(0.000)$ \\
& -0.065 & $0.061^{* * *}$ \\
Mean of bank size $(\log )$ & $(0.042)$ & $(0.008)$ \\
& $0.411^{* * *}$ & $0.202^{* * *}$ \\
Dispersion of bank size & $(0.149)$ & $(0.019)$ \\
& -0.104 & -0.033 \\
Skewness of bank size & $(0.240)$ & $(0.037)$ \\
& 0.160 & $0.025^{*}$ \\
Competition (Boone index) & $(0.103)$ & $(0.014)$ \\
& $0.618^{* *}$ & $-0.213^{* * *}$ \\
\hline$R^{2}$ & $(0.272)$ & $(0.059)$ \\
Obs. & 0.383 & 0.760 \\
\hline \hline
\end{tabular}

The top part of the table presents the results of the estimation of equation (1) using as dependent variable the logarithm of the value of international bank claims of the reporting country (lender) to banks in the partner country (borrower), instead of all international claims, on an immediate risk basis. The regression includes time*lenders and time*borrowers fixed effects. The bottom part of the table presents the results of the estimation of equations (2) and (3). The dependent variables are the time-varying time*lenders and time-borrowers fixed effects estimated from equation (1). All explanatory variables are defined in table 1 . Robust standard errors are reported in parenthesis. ${ }^{*}$ indicates significance at $10 \%$ level, ${ }^{* *}$ at $5 \%$ and ${ }^{* * *}$ at $1 \%$.

Table 8: Claims to banks 


\begin{tabular}{lc}
\hline \hline & First stage regression \\
\hline \hline & International claims to banks $(\log )$ \\
\hline Distance $(\log )$ & $-0.412^{* * *}$ \\
& $(0.011)$ \\
Common language & $0.902^{* * *}$ \\
& $(0.025)$ \\
Common colonizer & $0.833^{* * *}$ \\
& $(0.034)$ \\
Common legal origin & $-0.117^{* * *}$ \\
& $(0.018)$ \\
Common border & $0.642^{* * *}$ \\
& $(0.042)$ \\
\hline$R^{2}$ & 0.615 \\
Obs. & 136,424 \\
\hline \hline
\end{tabular}

\begin{tabular}{|c|c|c|}
\hline \multicolumn{3}{|c|}{ Second stage regression } \\
\hline & $\begin{array}{l}\text { Lenders' fixed effects } \\
\text { (1) }\end{array}$ & $\begin{array}{c}\text { Borrowers' fixed effects } \\
(2)\end{array}$ \\
\hline GDP $(\log )$ & $\begin{array}{c}0.500^{* * *} \\
(0.110)\end{array}$ & $\begin{array}{c}0.372^{* * *} \\
(0.040)\end{array}$ \\
\hline Bank assets/GDP & $\begin{array}{c}0.002 \\
(0.003)\end{array}$ & $\begin{array}{c}0.004^{* * *} \\
(0.001)\end{array}$ \\
\hline International fin. restr. & $\begin{array}{c}-4.463^{* * *} \\
(0.847)\end{array}$ & $\begin{array}{c}-0.629^{* * *} \\
(0.123)\end{array}$ \\
\hline Foreign banks (share) & $\begin{array}{c}0.001 \\
(0.004)\end{array}$ & $\begin{array}{c}0.005^{* * *} \\
(0.001)\end{array}$ \\
\hline Banks owned abroad (no.) & $\begin{array}{c}0.215^{* * * *} \\
(0.050)\end{array}$ & $\begin{array}{c}-0.051^{* *} \\
(0.025)\end{array}$ \\
\hline Mean of bank size $(\log )$ & $\begin{array}{c}0.699^{* * *} \\
(0.185)\end{array}$ & $\begin{array}{c}0.411^{* * *} \\
(0.056)\end{array}$ \\
\hline Dispersion of bank size & $\begin{array}{c}-1.165^{* * *} \\
(0.258)\end{array}$ & $\begin{array}{l}0.176^{*} \\
(0.099)\end{array}$ \\
\hline Skewness of bank size & $\begin{array}{c}0.413^{* * *} \\
(0.091)\end{array}$ & $\begin{array}{c}0.014 \\
(0.039)\end{array}$ \\
\hline Competition (Boone index) & $\begin{array}{l}0.809^{*} \\
(0.417)\end{array}$ & $\begin{array}{l}-0.176 \\
(0.157)\end{array}$ \\
\hline$R^{2}$ & 0.682 & 0.682 \\
\hline Obs. & 241 & 654 \\
\hline $\begin{array}{l}\text { The top part of the table preser } \\
\text { as dependent variable the logari } \\
\text { reporting country (lender) in the } \\
\text { risk basis, instead of on an imm } \\
\text { and time*borrowers fixed effects. } \\
\text { the estimation of equations }(2) \\
\text { time*lenders and time-borrowers } \\
\text { tory variables are defined in table } \\
{ }^{*} \text { indicates significance at } 10 \% \text { lev }\end{array}$ & $\begin{array}{l}\text { ts the results of the estim } \\
\text { hm of the value of intern } \\
\text { partner country (borrower } \\
\text { diate risk basis. The regre } \\
\text { The bottom part of the t } \\
\text { nd (3). The dependent var } \\
\text { fixed effects estimated from } \\
\text { 1. Robust standard errors } \\
\text { el, ** at } 5 \% \text { and *** at } 1 \% \text {. }\end{array}$ & $\begin{array}{l}\text { tion of equation (1) using } \\
\text { tional bank claims of the } \\
\text { measured on an ultimate } \\
\text { sion includes time*lenders } \\
\text { ble presents the results of } \\
\text { ables are the time-varying } \\
\text { equation (1). All explana- } \\
\text { re reported in parenthesis. }\end{array}$ \\
\hline
\end{tabular}

Table 9: Ultimate risk basis 


\begin{tabular}{|c|c|c|}
\hline \multicolumn{3}{|c|}{ Second stage regression } \\
\hline & $\begin{array}{l}\text { Lenders' fixed effects } \\
\text { (1) }\end{array}$ & $\begin{array}{c}\text { Borrowers' fixed effects } \\
(2)\end{array}$ \\
\hline \multirow[t]{2}{*}{ GDP $(\log )$} & -0.015 & $0.024^{* * *}$ \\
\hline & $(0.017)$ & $(0.008)$ \\
\hline \multirow[t]{2}{*}{ Bank assets/GDP } & -0.000 & -0.000 \\
\hline & $(0.000)$ & $(0.000)$ \\
\hline \multirow[t]{2}{*}{ Intern. fin. restricions } & $-0.326^{* * *}$ & $-0.066^{* * *}$ \\
\hline & $(0.050)$ & $(0.024)$ \\
\hline \multirow[t]{2}{*}{ Foreign banks (share) } & -0.000 & $0.001^{* * * *}$ \\
\hline & $(0.001)$ & $(0.000)$ \\
\hline \multirow[t]{2}{*}{ Banks owned abroad (no.) } & $0.105^{* * *}$ & $0.048^{* * *}$ \\
\hline & $(0.022)$ & $(0.008)$ \\
\hline \multirow[t]{2}{*}{ Mean (Bank asset distr.) (log) } & $0.218^{* * * *}$ & $0.109^{* * *}$ \\
\hline & $(0.029)$ & $(0.012)$ \\
\hline \multirow[t]{2}{*}{ Coeff. var. (Bank asset distr.) } & -0.039 & -0.008 \\
\hline & $(0.052)$ & $(0.021)$ \\
\hline \multirow[t]{2}{*}{ Skewness (Bank asset distr.) } & $0.081^{* * *}$ & $0.037^{* * *}$ \\
\hline & $(0.022)$ & $(0.009)$ \\
\hline \multirow[t]{2}{*}{ Skewness $*$ Foreign banks } & $-0.002^{* * *}$ & -0.000 \\
\hline & $(0.000)$ & $(0.000)$ \\
\hline \multirow[t]{2}{*}{ Skewness * Banks owned abroad } & $-0.010^{* * *}$ & $-0.005^{* * *}$ \\
\hline & $(0.003)$ & $(0.001)$ \\
\hline \multirow[t]{2}{*}{ Boone competition index } & -0.088 & 0.023 \\
\hline & $(0.078)$ & $(0.036)$ \\
\hline$R^{2}$ & 0.586 & 0.707 \\
\hline Obs. & 651 & 651 \\
\hline \multicolumn{3}{|c|}{$\begin{array}{l}\text { The top part of the table presents the results of the estimation of equation (1). The de- } \\
\text { pendent variable is the logarithm of the value of international bank claims of the reporting } \\
\text { country (lender) in the partner country (borrower), on an immediate risk basis. The re- } \\
\text { gression includes time*lenders and time*borrowers fixed effects. The bottom part of the } \\
\text { table presents the results of the estimation of equations }(2) \text { and (3). The dependent vari- } \\
\text { ables are the time-varying time*lenders and time-borrowers fixed effects estimated from } \\
\text { equation (1). All explanatory variables are defined in table } 1 \text {. Robust standard errors are } \\
\text { reported in parenthesis. }{ }^{*} \text { indicates significance at } 10 \% \text { level, }{ }^{* *} \text { at } 5 \% \text { and }{ }^{* * *} \text { at } 1 \% \text {. }\end{array}$} \\
\hline
\end{tabular}

Table 10: Interactions with incidence of foreign banks 


\section{References}

Acharya, V. V., 2003. Is the international convergence of capital adequacy regulation desirable? The Journal of Finance 58 (6), 2745-2782.

Affinito, M., Pozzolo, A. F., 2017. The interbank network across the global financial crisis: Evidence from Italy. Journal of Banking and Finance 80, 90-107.

Amiti, M., McGuire, P., D. E. Weinstein. 2017. Supply- and Demand-side Factors in Global Banking. NBER Working Paper No. 23536.

Anderson, J.E., van Wincoop, E., 2003. Gravity with gravitas: a solution to the border puzzle. The American Economic Review 93, 170-192.

Avdjiev, S., McGuire, P., Wooldridge, P., 2015. Enhanced data to analyse international banking. BIS Quarterly Review, September, 53-68.

Barba Navaretti, G., Bugamelli, M., Forlani, E., Ottaviano, G. I., 2015. It takes (more than) a moment: Revisiting the link between firm productivity and aggregate exports. Mimeo.

Barba Navaretti, G., Calzolari, G., Pozzolo, A. F., Levi, M., October 2010. Multinational banking in Europe - financial stability and regulatory implications: lessons from the financial crisis. Economic Policy 25, 703-753.

Bas, M., Mayer, T, Thoenig, M., 2015. From Micro to Macro: Demand, Supply, and Heterogeneity in the Trade Elasticity. Banque de France Working Paper No. 560, available at SSRN.

Beck, T., Levine, R., et al., 1999. A new database on financial development and structure. Vol. 2146. World Bank Publications.

Berger, A. N., Miller, N. H., Petersen, M. A., Rajan, R. G., Stein, J. C. (2005). Does function follow organizational form? Evidence from the lending practices of large and small banks. Journal of Financial economics 76, 237-269.

Bernard, A.B., Jensen, J.B., Redding, S.J., Schott, P.K., 2007. Firms in international trade. The Journal of Economic Perspectives 21, 105-130.

Boone, J., 2008. A new way to measure competition. The Economic Journal, 118, $1245-1261$.

Bouvatier, V., Delatte, A.-L., 2015. Waves of international banking integration: A tale of regional differences. European Economic Review 80 (C), 354-373.

Buch, C. M., Koch, C. T., Koetter, M., 2014a. Should I stay or should I go? bank productivity and internationalization decisions. Journal of Banking \& Finance $42,266-282$. 
Buch, C. M., Neugebauer, K., Schröder, C., 2014b. Changing forces of gravity: How the crisis affected international banking. ZEW-Centre for European Economic Research Discussion Paper (14-006).

Caballero, R. J., 2010. The "Other" Imbalance and the Financial Crisis. NBER Working Papers 15636, National Bureau of Economic Research, Inc.

Claessens, S., van Horen, N., 2014. Foreign banks: Trends and impact. Journal of Money, Credit and Banking 46, 295-326.

Coeurdacier, N., Martin, P., 2009. The geography of asset trade and the euro: Insiders and outsiders. Journal of the Japanese and International Economies 23, 90-113.

Daude, C., Fratzscher, M., 2008. The pecking order of cross-border investment. Journal of International Economics 74 (1), 94-119.

Duprey, T., Le, M., 2016. Bankscope Dataset: Getting Started.

Ennis, H. M., 2001. On the size distribution of banks. FRB Richmond Economic Quarterly 87 (4), 1-25.

Eaton, J., Kortum, S., 2001. Trade in capital goods. European Economic Review $45,1195-1235$.

Eaton, J., Kortum, S., 2002. Technology, geography, and trade. Econometrica 70, $1741-1779$.

Fernandez, A., Klein, M. W., Rebucci, A., Schindler, M., Uribe, M., 2015. Capital control measures: A new dataset. NBER Working Papers 20970, National Bureau of Economic Research, Inc.

Focarelli, D., Pozzolo, A.F., 2001. The patterns of cross-border bank mergers and shareholdings in OECD countries. Journal of banking and Finance 25, 2305-2337.

Gabaix, X., 2011. The granular origins of aggregate fluctuations. Econometrica $79(3), 733-772$.

Haldane, A. G., 2009. Comment on "Capital Flows and Asset Prices". In: NBER International Seminar on Macroeconomics 2007. NBER Chapters. National Bureau of Economic Research, Inc, pp. 217-223.

Head, K., Mayer, T., 2014. Gravity Equations: Workhorse, Toolkit, and Cookbook, in Helpman, E., Rogoff, K., Gopinath, G., (eds.), Handbook of International Economics, volume 4. Elsvier.

Head, K., Ries, J., 2008. FDI as an outcome of the market for corporate control: Theory and evidence. Journal of International Economics 74 (1), 2-20. 
Helpman, E., Melitz, ;.J., Yeaple, S.R.,2004. Export Versus FDI with Heterogeneous Firms. American Economic Review 94, 300-316.

Houston, J. F., Lin, C., Ma, Y., 2012. Regulatory arbitrage and international bank flows. The Journal of Finance 67 (5), 1845-1895.

Kleimeier, S., Sander, H., Heuchemer, S., 2014. The resurgence of cultural borders in international finance during the financial crisis: Evidence from eurozone crossborder depositing. Research Memorandum 013, Maastricht University, Graduate School of Business and Economics (GSBE).

Kose, M.A., Prasad, E., Rogoff, K., Wei, S.J., 2009. Financial globalization: A reappraisal. IMF Staff Papers 56, 8-62.

Lane, P.R., Milesi-Ferretti, G. M., 2007. The external wealth of nations mark II: Revised and extended estimates of foreign assets and liabilities, 1970-2004. Journal of international Economics 73, 223-250.

Liu, H., Molyneux, P., Wilson, J.O., 2013. Competition in banking: Measurement and interpretation, in Bell, A.R., Brooks, C., Prokopczuk, M. (eds.), Handbook Of Research Methods and Applications in Empirical Finance, Cheltenham, Edward Elgar.

Martin, P., Rey, H., 2004. Financial super-markets: size matters for asset trade. Journal of International Economics 64, 335-361.

Mayer, T., Zignago, S., 2011. Notes on CEPII's distances measures: the GeoDist Database. CEPII Working Paper 2011-25.

Melitz, M. J., 2003. The impact of trade on intra-industry reallocations and aggregate industry productivity. Econometrica 71 (6), 1695-1725.

Melitz, M., Redding, S., 2015. New Trade Models, New Welfare Implications. American Economic Review 105, 1105-1146.

Morrison, A. D., White, L., 2009. Level playing fields in international financial regulation. The Journal of Finance 64 (3), 1099-1142.

Niepmann, F., 2015. Banking across borders. Journal of International Economics 96 (2), $244-265$.

Niepmann, F., Schmidt-Eisenlohr, T., 2013. Banks in international trade finance: evidence from the U.S. Staff Reports 633, Federal Reserve Bank of New York.

Okawa, Y., van Wincoop, E., 2012. Gravity in International Finance. Journal of International Economics 87 (2), 205-215.

Ottaviano, G., Mayer, T., 2011. The happy few: the internationalisation of European firms. No. 12 in Blueprints. Bruegel. 
Papaioannou, E., 2009. What drives international financial flows? Politics, institutions and other determinants. Journal of Development Economics 88 (2), 269 281.

Pietrovito, F., Pozzolo, A. F., Salvatici, L., 2013. Internationalization choices: an ordered probit analysis at industry level. Empirical Economics, 1-34.

Portes, R., Rey, H., 2005. The determinants of cross-border equity flows. Journal of international Economics 65 (2), 269-296.

Redding, S., Venables, A.J., 2004. Economic geography and international inequality. Journal of International Economics 62, 53-82.

Rodrik, D., 1998. Symposium on globalization in perspective: An introduction. Journal of Economic Perspectives 12 (4), 3-8.

Schmidt-Eisenlohr, T., 2013. Towards a theory of trade finance. Journal of International Economics 91 (1), $96-112$.

Tinbergen, J., 1962. Shaping theWorld Economy: Suggestions for an International Economic Policy. Twentieth Century Fund, New-York. 